\title{
Review
}

\section{The Potentials of Methylene Blue as an Anti-Aging Drug}

\author{
Huijing Xue, Abhirami Thaivalappil (D) and Kan Cao* \\ Department of Cell Biology and Molecular Genetics, University of Maryland, College Park, MD 20742, USA; \\ hjxue05@umd.edu (H.X.); ami.thaivalappil@gmail.com (A.T.) \\ * Correspondence: kcao@umd.edu
}

\begin{abstract}
Methylene blue (MB), as the first fully man-made medicine, has a wide range of clinical applications. Apart from its well-known applications in surgical staining, malaria, and methemoglobinemia, the anti-oxidative properties of MB recently brought new attention to this century-old drug. Mitochondrial dysfunction has been observed in systematic aging that affects many different tissues, including the brain and skin. This leads to increaseding oxidative stress and results in downstream phenotypes under age-related conditions. MB can bypass Complex I/III activity in mitochondria and diminish oxidative stress to some degree. This review summarizes the recent studies on the applications of MB in treating age-related conditions, including neurodegeneration, memory loss, skin aging, and a premature aging disease, progeria.
\end{abstract}

Keywords: methylene blue; mitochondria; neurodegeneration; skin aging; progeria

check for updates

Citation: Xue, H.; Thaivalappil, A.; Cao, K. The Potentials of Methylene Blue as an Anti-Aging Drug. Cells 2021, 10, 3379. https://doi.org/ 10.3390/cells10123379

Academic Editors: Holger Bierhoff and Christoph Englert

Received: 10 October 2021

Accepted: 25 November 2021

Published: 1 December 2021

Publisher's Note: MDPI stays neutral with regard to jurisdictional claims in published maps and institutional affiliations.

Copyright: (c) 2021 by the authors. Licensee MDPI, Basel, Switzerland. This article is an open access article distributed under the terms and conditions of the Creative Commons Attribution (CC BY) license (https:// creativecommons.org/licenses/by/ $4.0 /)$.

\section{Introduction}

Methylene blue (MB) is a well-established drug, originally synthesized as a textile dye in 1876 [1]. The small molecular weight allows MB to be delivered into tissues fast. MB can be reduced into leucomethylene blue (leucoMB), and therefore, it can be used as an antioxidant (Figure 1A) [2]. MB is an FDA-approved medicine and has been widely used in surgical staining, malaria, methemoglobinemia, etc. [1].

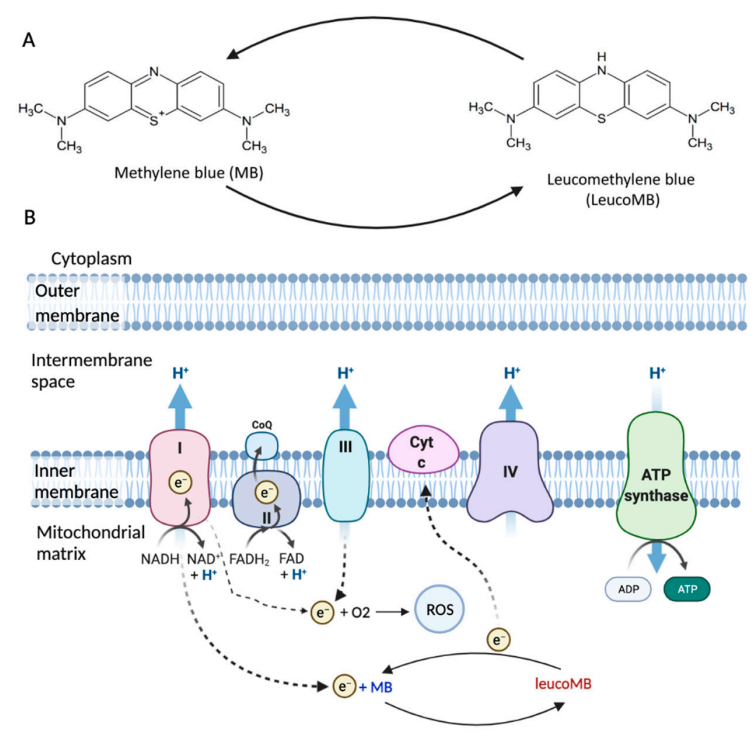

Figure 1. The structure and function of MB. (A) MB is a phenothiazine derivative, and its reduced form is leucoMB. (B) Mitochondrial electron transport chain (ETC) is associated with ATP production and ROS production. MB can work as a catalytic redox cycler in mitochondria and bypass Complex I/III activity (Figure adapted from “Electron Transport Chain”, by BioRender, 10 October 2021, retrieved from https:/ / app.biorender.com/biorender-templates/t-5edadc578a691400acf3c4ec-electrontransport-chain). 
According to the "free radicals theory of aging", cell and tissue aging are a result of free radicals' attacks [3]. In human cells, reactive oxygen species (ROS) are mainly produced in mitochondria [4], while aging, declines in mitochondrial mass, respiration capacity, and respiration efficiency were observed in different tissues [5]. Dysfunctional mitochondria lead to decreased ATP production and increased ROS production [6], which would further damage mitochondria. This vicious cycle leads to severe cellular damages and accelerates the aging process. $\mathrm{MB}^{\prime} \mathrm{s}$ antioxidative properties mainly improve mitochondrial function and break the ROS-mitochondrial damage cycle $[7,8]$, which makes it a great candidate as an anti-aging drug.

In this review, the structure, biological function, and applications of $\mathrm{MB}$ will be discussed.

\section{Structure and Functions}

A mitochondrion is a major energy source in eukaryotic cells, and the mitochondrial electron transport chain (ETC) is associated with ATP production [9]. ETC is a series of electron transporters located in the inner mitochondrial membrane that shuttles electrons from $\mathrm{NADH}$ and FADH2 to molecular oxygen (Figure 1B). ETC consists of four complexes, with Complex I (NADH-ubiquinone oxidoreductase) and Complex II (succinate dehydrogenase) being the entrances for electrons, and $\mathrm{NADH}$ and $\mathrm{FADH}_{2}$ transfer the electrons to Complex I and Complex II, respectively [10]. These electrons are transported by Complexes III (CoQ-cytochrome c reductase) and IV (cytochrome c oxidase), with the help of ubiquinone (Co-enzyme Q10, CoQ) and cytochrome c. Complex III passes the electrons to cytochrome c, and Complex IV transfers the electrons from cytochrome $\mathrm{c}$ to the terminal electron acceptor $\mathrm{O}_{2}$ to generate $\mathrm{H}_{2} \mathrm{O}$ [11]. In this process, Complex V (ATP synthase) will produce ATP by phosphorylating ADP. About $0.4 \%$ to $4 \%$ oxygen is partially reduced under physiological conditions, with ROS being the byproduct [12]. There are 11 sites of ROS generation in the ETC, however, it is mainly produced in Complex I [13,14]. Mitochondrial dysfunction can lead to oxidative damage, which primarily impairs Complex IV as well as Complex I [15]. While Complex I is impaired, overproduction of ROS can result in increased oxidative stress and therefore induce cellular damages [4].

$\mathrm{MB}$ is a phenothiazine derivative and can be reduced into leucoMB (Figure 1A). In its oxidized state, MB solution is blue, while leucoMB is colorless [16]. MB is hydrophilic and lipophilic, which makes it highly permeable through biomembranes [17]. MB is also positively charged [18]. The redox potential of $\mathrm{MB}$ is $11 \mathrm{mV}$, and it can cycle readily between oxidized and reduced forms in mitochondria because of its low redox potential [8]. Such characteristics allow MB to work as a catalytic redox cycler in mitochondria, promoting cytochrome oxidase activity and ATP production (Figure 1). MB also decreases the production of ROS via bypassing Complex I/III activity $[18,19]$. MB receives electrons from $\mathrm{NADH}$ through Complex I, converting to leucoMB. LeucoMB can directly transfer these electrons to cytochrome c, re-oxidized to MB. Therefore, MB has the potential to protect cells against oxidative stress under pathological conditions.

MB has been widely used in surgical staining, malaria, and methemoglobinemia [1]. Additionally, MB was shown to photo-inactivate bacteria in 1928 [20], and its potent antiviral effects were discovered soon after [21]. MB can also be used as an anti-fungal and anti-parasitic aquarium disinfectant, even with very high dosages (millimolar) [22,23]. MB has also been used in photodynamic therapy among different types of cancers, including lung cancer [24], breast cancer [25], and prostate cancer [26]. Surprisingly, a French study involving 2500 patients treated with $\mathrm{MB}$ and standard chemotherapy showed no cases of COVID-19 infection [27]. A study showed that low doses $(0.5-4 \mathrm{mg} / \mathrm{kg})$ of MB are effective to stimulate mitochondrial respiration in vivo and safe in animals and humans [17]. Such evidence suggested that $\mathrm{MB}$ is a safe drug. 


\section{Applications}

\section{1. $M B$ in Brain Aging}

Oxidative metabolism is an important energy source for brain activity [28]. During brain aging, mitochondrial dysfunction has been associated with neuronal loss. It has also been observed in many brain diseases, such as Alzheimer's disease (AD), Parkinson's disease (PD), and brain injuries [29]. MB is highly lipophilic and able to effectively cross the blood-brain barrier (BBB) [17]. MB concentration is found to be higher in the brain than in plasma after oral administration or intravenous injection in rats [30]. Besides, it has a strong affinity for mitochondria [31]. Different from the other antioxidants such as MitoQ and MitoVitE, MB can reduce the production of free radicals by bypassing Complex I/III activity rather than scavenging free radicals [32]. In fact, the membrane potential in Complex III-inhibited mitochondria can be partially restored by MB in both mice and rats [18]. MB, acting as an electron donor, can also increase the expression of brain cytochrome oxidase and oxygen consumption in vivo [33,34]. Besides, low doses of $\mathrm{MB}$ were shown to effectively inhibit nitric oxide (NO), which inhibits cytochrome c oxidase activity $[35,36]$. All these properties make MB a promising drug candidate for brain diseases' treatment.

$\mathrm{AD}$ is a neurodegenerative disease that constitutes a significant portion of dementia [37]. Amyloid- $\beta$ (A $\beta$ ) aggregation and neurofibrillary tangles (NFTs) are two pathological hallmarks of AD [38]. Aging is one of the most important risk factors of AD [39]. Mitochondrial dysfunction could be a missing link between aging and AD: at the early stage of AD progression, elevated mitochondria-derived oxidative stress has been reported $[40,41]$. Mitochondria with reduced size and impaired movement were also observed in the AD brain [42]. Moreover, mitochondrial dysfunction causes diminished energy metabolism, alterations in the key enzymes in oxidative phosphorylation, dysregulation of calcium homeostasis, and elevated levels of sporadic mutations in the mtDNA in AD [41]. Lowdose treatment with $\mathrm{MB}$ can reduce ROS production, which could be beneficial to AD patients [43].

Several studies suggest that there is an association between mitochondrial dysfunction and abnormal processing of $\mathrm{A} \beta$ and tau [44-47]. Amyloid precursor protein (APP) can be trapped in the mitochondrial membrane and impair mitochondrial function [48]. Overexpression of tau can also result in mitochondrial dysfunction by decreasing ATP production and increasing oxidative stress [49]. Conversely, the damaged mitochondrial function can induce aberrant $\mathrm{A} \beta$ production and promote abnormal phosphorylation of tau [50]. $\mathrm{MB}$ was reported to prevent $A \beta$ and tau aggregation or dissolve existing aggregates via autophagic clearance, and therefore alleviate downstream pathological consequences [51-54]. MB could directly or indirectly target $\beta$-secretase cleavage of amyloid precursor protein (APP) and regulate the generation of $\mathrm{A} \beta$ [55]. MB's role in $\mathrm{A} \beta$ and tau aggregation clearance may help improve mitochondrial functions in AD neurons and thus contribute to AD treatment. Besides, cytochrome oxidase activity has been shown to decline in AD [56], while MB can increase the enzymatic activity of cytochrome oxidase, which results in an increased oxidative metabolic capacity of neurons [57].

The efficacy of MB in AD clinical treatment is still under investigation. In AD transgenic mouse models, $\mathrm{MB}$ can inhibit $\mathrm{A} \beta$ production and rescue the cognitive defects $[58,59]$. In 2008, a research group presented preliminary data showing that low-dose MB prevented cognitive impairment in AD patients. Rember, which is the commercial name of MB, was administered to patients with mild to moderate symptoms. The result showed that there was an $81 \%$ reduction in the rate of cognitive decline in 50 weeks [60]. In the phase 2 clinical trial, Rember was shown to improve both cognitive and cerebral blood flow in patients with mild to moderate AD [61]. LMTM, a stable variant form of MB, has been tested in a phase 3 clinical trial [62]. However, the result was inconclusive due to the lack of using the proper placebo control group [62]. Another non-randomized cohort analysis has been performed more recently, which showed that the brain atrophy rate in patients 
with mild AD declined after a 9-month treatment [63]. Still, treatment dosage and proper control group should be optimized, and a further suitably randomized trial is needed.

$\mathrm{PD}$ is another neurodegenerative disease associated with aging. It is one of the most common movement diseases featured by dopaminergic neuronal damage [64]. The pathological hallmark of PD is Lewy Bodies and Lewy Neurites, intracellular aggregates of the protein $\alpha$-synuclein ( $\alpha$-syn) [65]. A-syn can lead to progressive mitochondrial dysfunction when translocated to the mitochondria [66]. Mitochondrial dysfunction is considered the primary cause of dopaminergic apoptosis via inducing oxidative stress in $\mathrm{PD}$ [67]. Based on MB's role in improving mitochondrial function, $\mathrm{MB}$ could be a promising treatment in PD. Significant beneficial effects in reducing nigrostriatal dopaminergic loss and motor impairment can be observed in the rat rotenone models [68,69]. MB was able to preserve dopamine neurons to some degree and alleviate motor defects in a PD 6-OHDA mouse model [70]. Low-dose MB treatment is also effective in a chronic toxin-induced mouse model [32]. However, more evidence is still needed to confirm whether MB can be used as a PD treatment.

In addition to its beneficial role in age-related brain disorders, $\mathrm{MB}$ is a promising memory enhancer. Since metabolic derangement is observed in old brains, and mitochondrial impairment accumulates over time, improving mitochondria may help neurons maintain their health and improve their functions [71-73]. Several early studies have shown that MB could enhance memory retention by increasing cytochrome oxidase activity and facilitating ATP generation in rats and zebrafish at low dosages $[34,74,75]$. One of these studies showed that brain cytochrome oxidase activity after MB treatment was about $70 \%$ higher than in the control group, and the overall mnemonic capacity during discrimination learning was improved [74]. These effects were accompanied by long-lasting mitochondrial respiratory function [33]. Another study showed that MB could prevent memory impairment in rats with chronic cerebral hypoperfusion [76]. With functional imaging in the human brain, it was shown that MB could modulate task-related and resting-state neural networks [77]. Therefore, MB has the potential to protect cognition against accelerated aging.

\section{2. $M B$ in Skin Aging}

As one of the body's largest and most complex organs and the primary defense against the external environment, the skin serves a critical health function [78]. There are three primary layers of skin (Figure 2): the epidermis, the dermis, and the subcutis [79]. Keratinocytes and melanocytes localize to the innermost layer of the epidermis, called the basal cell layer [79]. The dermis contains fibroblasts, which synthesize extracellular proteins such as collagen and elastin [79]. The subcutis is also known as the hypodermis, the layer of subcutaneous fat that provides insulation [79].

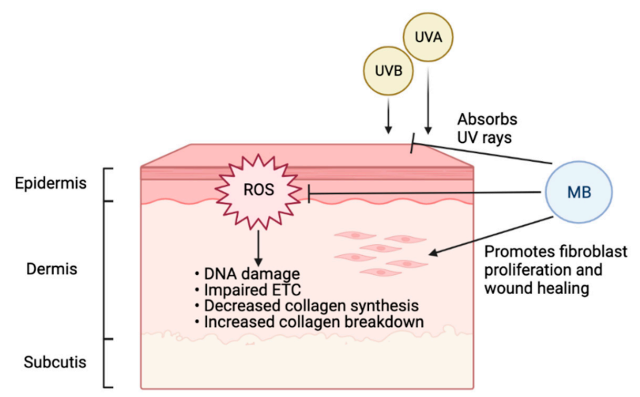

Figure 2. Beneficial effects of MB on human skin. Environmental factors, especially UV radiation, cause the accumulation of ROS on skin, leading to DNA damage, impaired ETC, decreased collagen synthesis, and increased collagen breakdown. As a potent antioxidant, MB can effectively combat ROS and presents the accelerated aging induced by ROS. In addition, MB can stimulate fibroblast proliferation, thereby promoting wound healing. Furthermore, MB is a broad-spectrum UV chemical blocker (Figure created with BioRender.com, 10 October 2021). Together, MB renders three levels of protection to human skin, from blocking UV irradiation, mitigating the cellular oxidative damages, to stimulating skin proliferation and wound healing. 
Aging is an inevitable process that afflicts the skin. It is characterized by loss of elasticity, thinness, flattening of the dermal-epidermal junction, atrophy of the extracellular matrix (ECM), and ROS [80]. There are two different types of skin aging, intrinsic and extrinsic [81]. Intrinsic aging manifests in the natural physiologic factors: as the proliferation of the basal cell layer decreases, skin cells reach senescence, and collagen expression is downregulated [81]. Extrinsic skin aging expedites aging through environmental factors, causing thickening of the epidermis, decreased proliferation of basal cells, collagen downregulation, and increased oxidative stress [81]. A large fraction of extrinsic aging comes from photodamage accumulated by ultraviolet (UV) rays [82]. Oxidative stress is involved in both intrinsic and extrinsic skin aging [83]. Especially when skin is exposed to certain environmental risk factors such as UV radiation, increasing oxidative damage will decrease collagen synthesis and increase collagen breakdown, leading to accelerated aging [84]. Antioxidants such as MB can therefore protect skin and slow down the aging process (Figure 2).

A previous study has shown that MB treatment in normal fibroblasts could increase lifespan and cell proliferation while reducing aging markers [85]. In that study, MB increased cytochrome oxidase by $30 \%$, enhanced oxygen consumption by $37-70 \%$, and reversed premature senescence caused by $\mathrm{H}_{2} \mathrm{O}_{2}$ or cadmium, and the ratio $\mathrm{MB} /$ cytochrome c could be important for MB's protective role. Interestingly, when MB was compared with common antioxidants used in skincare, including vitamin $C$ and retinol (vitamin A), MB-treated skin cells outperformed both of them significantly in terms of promoting cell proliferation and reducing age-related markers $[86,87]$. In addition to its potent antioxidant function, $\mathrm{MB}$ treatment in skin fibroblasts could stimulate the expression of ECM proteins, including upregulation of elastin and collagen 2A1 [86]. Furthermore, MB treatment improved skin thickness and hydration in a 3D skin tissue model [86]. Our recent study showed that $\mathrm{MB}$ provides broad-spectrum absorption of UV rays and mitigates DNA double-strand breaks caused by UVB irradiation in human keratinocytes [87]. Together, this evidence supports $\mathrm{MB}$ as protective and beneficial to human skin, suggesting that the inclusion of $\mathrm{MB}$ in daily skincare may effectively delay photoaging.

MB can facilitate wound healing. During aging, the proliferation and migration of fibroblasts are often decreased, and collagen and elastin in the ECM are degraded [88]. Therefore, the repair capabilities of the skin decline due to structural and functional changes. Our study indicated that MB treatment could promote fibroblast migration and proliferation in the wound healing process [86]. In skin survival burn models in rats, MB treatment could reduce necrosis progression, which might be mediated by decreasing oxidative stress through blocking nitric oxide (NO) [89]. Moreover, MB can facilitate wound healing by reducing antimicrobial burden and decreasing hyper-granulation. $\mathrm{MB}$ also has a drying effect without harming healthy cells [90-92]. Overall, MB was shown to improve tissue viability with little to no irritation in laboratory models.

\section{3. $M B$ in Progeria}

MB has shown potential for the treatment of Hutchinson-Gilford Progeria Syndrome (HGPS), which is a genetic, premature aging disorder caused by a $\mathrm{C}$ to $\mathrm{T}$ de novo point mutation on exon 11 of the $L M N A$ gene [93]. The mutation causes the production of progerin in the place of Lamin A, which holds a cryptic splice site that results in a 50 amino acids deletion of the protein [93]. The deletion removes a critical protease cleavage site, making progerin an aberrant form of pre-Lamin A with a permanent farnesyl modification. Progerin is then localized to the nuclear envelope, where it becomes fixed in the nuclear membrane [93]. Progerin disrupts the nuclear skeleton, leading to nuclear abnormalities, blebbing of the nuclear envelope, transcriptional changes, and severe cellular stress, which ultimately manifest as a rapid aged phenotype in patients [94-96]. Mitochondrial dysfunction is observed in both HGPS fibroblasts and animal models, with elevated levels of mitochondrial-specific superoxide (MitoSOX), ROS, and suppression of the mitochondrial biosynthesis gene PGC- $1 \alpha[97,98]$. 
As a mitochondrial antioxidant and highly permeable molecule, MB has demonstrated the ability to rescue HGPS phenotypes [99]. Our group found that MB treatment not only reduced mitochondrial defects but also rescued the transcriptional changes in HGPS. Besides, $\mathrm{MB}$ demonstrates the ability to solubilize progerin in the nuclear envelope, correcting the blebbed nuclei of HGPS cells and drastically reducing cellular stress. Whether these effects are related to MB's antioxidant characteristic is still unclear.

\section{Discussion}

Aging is a complex process with multiple contributing factors. This review discussed the anti-aging effects of $\mathrm{MB}$ with a focus on the relationship between mitochondrial dysfunction and aging. Brain aging is a mystery and neurodegenerative disorders are a major part. Currently, no cure is fully developed for most neurodegenerative diseases, including $\mathrm{AD}$ and PD. Several observations suggest that mitochondrial dysfunction is a key pathogenic step in neurodegenerative conditions [100]. In addition to having antioxidative properties, $\mathrm{MB}$ also crosses the $\mathrm{BBB}$ easily, making it a promising candidate for treatment. In $\mathrm{AD}$ mouse models, low-dosage $\mathrm{MB}$ shows its ability to relieve oxidative stress and rescue cognitive defects [58,59]. However, the results in phase 2 and phase 3 clinical trials are controversial $[62,63,101]$. This could be due to the translational limitations of mouse models. The design of clinical trials needs to be further optimized. Moreover, several studies suggest that $\mathrm{MB}$ can alleviate behavioral defects in PD mouse models [70]. Studies show that, even with physiological brain aging, MB treatment could still enhance memory by increasing cytochrome oxidase activity and decreasing oxidative stress [52-56]. However, more extensive studies are required to validate the clinical applications of $\mathrm{MB}$ in brain aging. MB has the ability to delay skin aging as well. MB can increase cell longevity, protect skin from UV exposure, and accelerate and help with the wound healing process $[86,87]$. Additionally, MB's antimicrobial properties are beneficial for skin [79-81]. Furthermore, a recent study proved that MB treatment resulted in significant improvements in HGPS skin fibroblast phenotypes (an accelerated form of the aging disease) [99].

Since MB is an FDA-approved medicine with a long history, the safety of MB usage has been thoroughly evaluated. The exploration of MB utilization in aging-related conditions can help us understand the aging process. Derivatives of MB can also be developed to improve its effects.

Author Contributions: The authors confirm contribution to the paper as follows: study conception and design: H.X. and K.C.; draft manuscript preparation and literature search: H.X., A.T., K.C.; revision: H.X. and K.C. All authors have read and agreed to the published version of the manuscript.

Funding: This research is supported by NIH R01HL126784.

Conflicts of Interest: K.C is the founder of Mblue Labs, which is a biotech company that focuses on skincare and public health. H.X. and A.T. declare no conflict of interest.

\section{References}

1. Schirmer, R.H.; Adler, H.; Pickhardt, M.; Mandelkow, E. “Lest we forget you-Methylene blue ... ". Neurobiol. Aging 2011, 32, 2325.e7-2325.e16. [CrossRef] [PubMed]

2. Oz, M.; Lorke, D.E.; Hasan, M.; Petroianu, G.A. Cellular and molecular actions of Methylene Blue in the nervous system. Med. Res. Rev. 2011, 31, 93-117. [CrossRef]

3. Harman, D. Aging: A Theory Based on Free Radical and Radiation Chemistry. J. Gerontol. 1956, 11, 298-300. [CrossRef]

4. Murphy, M.P. How mitochondria produce reactive oxygen species. Biochem. J. 2009, 417, 1-13. [CrossRef]

5. Chistiakov, D.A.; Sobenin, I.A.; Revin, V.V.; Orekhov, A.N.; Bobryshev, Y.V. Mitochondrial aging and age-related dysfunction of mitochondria. Biomed. Res. Int. 2014, 2014, 238463. [CrossRef] [PubMed]

6. Guo, C.Y.; Sun, L.; Chen, X.P.; Zhang, D.S. Oxidative stress, mitochondrial damage and neurodegenerative diseases. Neural Regen. Res. 2013, 8, 2003-2014. [CrossRef]

7. Gabrielli, D.; Belisle, E.; Severino, D.; Kowaltowski, A.J.; Baptista, M.S. Binding, Aggregation and Photochemical Properties of Methylene Blue in Mitochondrial Suspensions. Photochem. Photobiol. 2004, 79, 227. [CrossRef] [PubMed]

8. Atamna, H.; Kumar, R. Protective role of methylene blue in Alzheimer's disease via mitochondria and cytochrome c oxidase. J. Alzheimers Dis. 2010, 20, S439-S452. [CrossRef] 
9. Kühlbrandt, W. Structure and function of mitochondrial membrane protein complexes. BMC Biol. 2015, 13, 89. [CrossRef]

10. Nolfi-Donegan, D.; Braganza, A.; Shiva, S. Mitochondrial electron transport chain: Oxidative phosphorylation, oxidant production, and methods of measurement. Redox Biol. 2020, 37, 101674. [CrossRef] [PubMed]

11. Zhao, R.; Jiang, S.; Zhang, L.; Yu, Z. Mitochondrial electron transport chain, ROS generation and uncoupling (Review). Int. J. Mol. Med. 2019, 44, 3-15. [CrossRef]

12. Bhat, A.H.; Dar, K.B.; Anees, S.; Zargar, M.A.; Masood, A.; Sofi, M.A.; Ganie, S.A. Oxidative stress, mitochondrial dysfunction and neurodegenerative diseases; a mechanistic insight. Biomed. Pharmacother. 2015, 74, 101-110. [CrossRef] [PubMed]

13. Kowaltowski, A.J.; de Souza-Pinto, N.C.; Castilho, R.F.; Vercesi, A.E. Mitochondria and reactive oxygen species. Free Radic. Biol. Med. 2009, 47, 333-343. [CrossRef]

14. Brand, M.D. Mitochondrial generation of superoxide and hydrogen peroxide as the source of mitochondrial redox signaling. Free Radic. Biol. Med. 2016, 100, 14-31. [CrossRef]

15. Zorov, D.B.; Juhaszova, M.; Sollott, S.J. Mitochondrial Reactive Oxygen Species (ROS) and ROS-Induced ROS Release. Physiol. Rev. 2014, 94, 909-950. [CrossRef] [PubMed]

16. Lee, S.K.; Mills, A. Novel photochemistry of leuco-Methylene Blue. Chem. Commun. 2003, 3, 2366-2367. [CrossRef]

17. Rojas, J.C.; Bruchey, A.K.; Gonzalez-Lima, F. Neurometabolic mechanisms for memory enhancement and neuroprotection of methylene blue. Prog. Neurobiol. 2012, 96, 32-45. [CrossRef] [PubMed]

18. Sváb, G.; Kokas, M.; Sipos, I.; Ambrus, A.; Tretter, L. Methylene blue bridges the inhibition and produces unusual respiratory changes in complex iii-inhibited mitochondria. Studies on rats, mice and guinea pigs. Antioxidants 2021, 10, 305. [CrossRef]

19. Tretter, L.; Horvath, G.; Hölgyesi, A.; Essek, F.; Adam-Vizi, V. Enhanced hydrogen peroxide generation accompanies the beneficial bioenergetic effects of methylene blue in isolated brain mitochondria. Free Radic. Biol. Med. 2014, 77, 317-330. [CrossRef]

20. Schultz, E.W. Inactivation of Staphyloccus Bacteriophage by Methylene Blue. Exp. Biol. Med. 1928, 26, 100-101. [CrossRef]

21. Perdrau, J.R.; Charles, T. The photodynamic action of methylene blue on certain viruses. Proc. R. Soc. Lond. Ser. B Boil. Sci. 1933, 112, 288-298. [CrossRef]

22. Chambel, J.; Costa, R.; Gomes, M.; Mendes, S.; Baptista, T.; Pedrosa, R. Hydrogen peroxide, iodine solution and methylene solution highly enhance the hatching rate of freshwater ornamental fish species. Aquac. Int. 2014, 22, 1743-1751. [CrossRef]

23. Peneyra, S.M.; Lerpiriyapong, K.; Riedel, E.R.; Lipman, N.S.; Lieggi, C. Impact of Pronase, Sodium Thiosulfate, and Methylene Blue Combinations on Development and Survival of Sodium Hypochlorite Surface-Disinfected Zebrafish (Danio rerio) Embryos. Zebrafish 2020, 17, 342-353. [CrossRef]

24. Lim Jin, E.; Oak, C.-H.; Heo, J.; Kim, Y.-H. Methylene blue-mediated photodynamic therapy enhances apoptosis in lung cancer cells. Oncol. Rep. 2013, 30, 856-862. [CrossRef]

25. dos Santos, A.F.; Terra, L.F.; Wailemann, R.A.M.; Oliveira, T.C.; Gomes, V.D.M.; Mineiro, M.F.; Meotti, F.C.; Bruni-Cardoso, A.; Baptista, M.S.; Labriola, L. Methylene blue photodynamic therapy induces selective and massive cell death in human breast cancer cells. BMC Cancer 2017, 17, 194. [CrossRef]

26. Shanthi, P.T.; Foes, A.; Munirathinam, G. Abstract 2958: Evaluating the Therapeutic Effects of Methylene Blue against Prostate Cancer. Exp. Mol. Ther. 2019, 79, 2958.

27. Henry, M.; Summa, M.; Patrick, L.; Schwartz, L. A cohort of cancer patients with no reported cases of SARS-CoV-2 infection: The possible preventive role of Methylene Blue. Substantia 2020, 4, 888. [CrossRef]

28. Du, F.; Zhu, X.H.; Zhang, Y.; Friedman, M.; Zhang, N.; Uğurbil, K.; Chen, W. Tightly coupled brain activity and cerebral ATP metabolic rate. Proc. Natl. Acad. Sci. USA 2008, 105, 6409-6414. [CrossRef]

29. Nitzan, K.; Benhamron, S.; Valitsky, M.; Kesner, E.E.; Lichtenstein, M.; Ben-Zvi, A.; Ella, E.; Segalstein, Y.; Saada, A.; LorberboumGalski, H.; et al. Mitochondrial Transfer Ameliorates Cognitive Deficits, Neuronal Loss, and Gliosis in Alzheimer's Disease Mice. J. Alzheimers Dis. 2019, 72, 587-604. [CrossRef]

30. Peter, C.; Hongwan, D.; Küpfer, A.; Lauterburg, B.H. Pharmacokinetics and organ distribution of intravenous and oral methylene blue. Eur. J. Clin. Pharmacol. 2000, 56, 247-250. [CrossRef]

31. Klosowski, E.M.; de Souza, B.T.L.; Mito, M.S.; Constantin, R.P.; Mantovanelli, G.C.; Mewes, J.M.; Bizerra, P.F.V.; Menezes, P.V.M.D.C.; Gilglioni, E.H.; Utsunomiya, K.S.; et al. The photodynamic and direct actions of methylene blue on mitochondrial energy metabolism: A balance of the useful and harmful effects of this photosensitizer. Free Radic. Biol. Med. 2020, 153, 34-53. [CrossRef] [PubMed]

32. Biju, K.C.; Evans, R.C.; Shrestha, K.; Carlisle, D.C.B.; Gelfond, J.; Clark, R.A. Methylene Blue Ameliorates Olfactory Dysfunction and Motor Deficits in a Chronic MPTP/Probenecid Mouse Model of Parkinson's Disease. Neuroscience 2018, 380, 111-122. [CrossRef] [PubMed]

33. Gonzalez-Lima, F.; Barksdale, B.R.; Rojas, J.C. Mitochondrial respiration as a target for neuroprotection and cognitive enhancement. Biochem. Pharmacol. 2014, 88, 584-593. [CrossRef]

34. Riha, P.D.; Bruchey, A.K.; Echevarria, D.J.; Gonzalez-Lima, F. Memory facilitation by methylene blue: Dose-dependent effect on behavior and brain oxygen consumption. Eur. J. Pharmacol. 2005, 511, 151-158. [CrossRef] [PubMed]

35. Mayer, B.; Brunner, F.; Schmidt, K. Inhibition of nitric oxide synthesis by methylene blue. Biochem. Pharmacol. 1993, 45, 367-374. [CrossRef]

36. Brown, G.C.; Borutaite, V. Nitric oxide, cytochrome c and mitochondria. Biochem. Soc. Symp. 1999, 66, 17-25. [CrossRef] [PubMed] 
37. Erkkinen, M.G.; Kim, M.O.; Geschwind, M.D. Clinical Neurology and Epidemiology of the Major Neurodegenerative Diseases. Cold Spring Harb. Perspect. Biol. 2018, 10, a033118. [CrossRef]

38. Stelzmann, R.A.; Norman Schnitzlein, H.; Reed Murtagh, F. An english translation of alzheimer's 1907 paper, “Uber eine eigenartige Erkankung der Hirnrinde". Clin. Anat. 1995, 8, 429-431. [CrossRef]

39. Niccoli, T.; Partridge, L. Ageing as a Risk Factor for Disease. Curr. Biol. 2012, 22, R741-R752. [CrossRef] [PubMed]

40. Nunomura, A.; Perry, G.; Aliev, G.; Hirai, K.; Takeda, A.; Balraj, E.K.; Jones, P.K.; Ghanbari, H.; Wataya, T.; Shimohama, S.; et al. Oxidative damage is the earliest event in Alzheimer disease. J. Neuropathol. Exp. Neurol. 2001, 60, 759-767. [CrossRef] [PubMed]

41. Wang, X.; Wang, W.; Li, L.; Perry, G.; Lee, H.-G.; Zhu, X. Oxidative stress and mitochondrial dysfunction in Alzheimer's disease. Biochim. Biophys. Acta-Mol. Basis Dis. 2014, 1842, 1240-1247. [CrossRef]

42. Cavendish, J.Z.; Sarkar, S.N.; Colantonio, M.A.; Quintana, D.D.; Ahmed, N.; White, B.A.; Engler-Chiurazzi, E.B.; Simpkins, J.W. Mitochondrial Movement and Number Deficits in Embryonic Cortical Neurons from 3xTg-AD Mice. J. Alzheimers Dis. 2019, 70, 139-151. [CrossRef]

43. Poteet, E.; Winters, A.; Yan, L.J.; Shufelt, K.; Green, K.N.; Simpkins, J.W.; Wen, Y.; Yang, S.H. Neuroprotective Actions of Methylene Blue and Its Derivatives. PLoS ONE 2012, 7, e48279. [CrossRef] [PubMed]

44. Hansson Petersen, C.A.; Alikhani, N.; Behbahani, H.; Wiehager, B.; Pavlov, P.F.; Alafuzoff, I.; Leinonen, V.; Ito, A.; Winblad, B.; Glaser, E.; et al. The amyloid $\beta$-peptide is imported into mitochondria via the TOM import machinery and localized to mitochondrial cristae. Proc. Natl. Acad. Sci. USA 2008, 105, 13145-13150. [CrossRef] [PubMed]

45. Eckert, A.; Pagani, L. Amyloid-beta interaction with mitochondria. Int. J. Alzheimers Dis. 2011, 2011, 1-12. [CrossRef]

46. Cheng, Y.; Bai, F. The association of tau with mitochondrial dysfunction in Alzheimer's disease. Front. Neurosci. 2018, 12, 2014-2019. [CrossRef]

47. Szabo, L.; Eckert, A.; Grimm, A. Insights into disease-associated Tau impact on mitochondria. Int. J. Mol. Sci. 2020, $21,6344$. [CrossRef]

48. Anandatheerthavarada, H.K.; Biswas, G.; Robin, M.A.; Avadhani, N.G. Mitochondrial targeting and a novel transmembrane arrest of Alzheimer's amyloid precursor protein impairs mitochondrial function in neuronal cells. J. Cell Biol. 2003, 161, 41-54. [CrossRef]

49. Li, X.C.; Hu, Y.; Wang, Z.H.; Luo, Y.; Zhang, Y.; Liu, X.P.; Feng, Q.; Wang, Q.; Ye, K.; Liu, G.P.; et al. Human wild-type full-length tau accumulation disrupts mitochondrial dynamics and the functions via increasing mitofusins. Sci. Rep. 2016, 6, 1-10. [CrossRef]

50. Swerdlow, R.H. Mitochondria and Mitochondrial Cascades in Alzheimer's Disease. J. Alzheimers Dis. 2018, 62, 1403-1416. [CrossRef]

51. Necula, M.; Breydo, L.; Milton, S.; Kayed, R.; Van Der Veer, W.E.; Tone, P.; Glabe, C.G. Methylene blue inhibits amyloid A $\beta$ oligomerization by promoting fibrillization. Biochemistry 2007, 46, 8850-8860. [CrossRef] [PubMed]

52. Medina, D.X.; Caccamo, A.; Oddo, S. Methylene blue reduces A $\beta$ levels and rescues early cognitive deficit by increasing proteasome activity. Brain Pathol. 2011, 21, 140-149. [CrossRef]

53. Hosokawa, M.; Arai, T.; Masuda-Suzukake, M.; Nonaka, T.; Yamashita, M.; Akiyama, H.; Hasegawa, M. Methylene Blue Reduced Abnormal Tau Accumulation in P301L Tau Transgenic Mice. PLoS ONE 2012, 7, e52389. [CrossRef] [PubMed]

54. Lee, B., II; Suh, Y.S.; Chung, Y.J.; Yu, K.; Park, C.B. Shedding Light on Alzheimer's $\beta$-Amyloidosis: Photosensitized Methylene Blue Inhibits Self-Assembly of $\beta$-Amyloid Peptides and Disintegrates Their Aggregates. Sci. Rep. 2017, 7, 1-10. [CrossRef]

55. Mori, T.; Koyama, N.; Segawa, T.; Maeda, M.; Maruyama, N.; Kinoshita, N.; Hou, H.; Tan, J.; Town, T. Methylene Blue Modulates $\beta$-Secretase, Reverses Cerebral Amyloidosis, and Improves Cognition in Transgenic Mice. J. Biol. Chem. 2014, 289 , 30303-30317. [CrossRef] [PubMed]

56. Praticò, D. Oxidative stress hypothesis in Alzheimer's disease: A reappraisal. Trends Pharmacol. Sci. 2008, 29, 609-615. [CrossRef] [PubMed]

57. Oz, M.; Lorke, D.E.; Petroianu, G.A. Methylene blue and Alzheimer's disease. Biochem. Pharmacol. 2009, 78, 927-932. [CrossRef] [PubMed]

58. Paban, V.; Manrique, C.; Filali, M.; Maunoir-Regimbal, S.; Fauvelle, F.; Alescio-Lautier, B. Therapeutic and preventive effects of methylene blue on Alzheimer's disease pathology in a transgenic mouse model. Neuropharmacology 2014, 76, 68-79. [CrossRef] [PubMed]

59. Hochgräfe, K.; Sydow, A.; Matenia, D.; Cadinu, D.; Könen, S.; Petrova, O.; Pickhardt, M.; Goll, P.; Morellini, F.; Mandelkow, E.; et al. Preventive methylene blue treatment preserves cognition in mice expressing full-length pro-aggregant human Tau. Acta Neuropathol. Commun. 2015, 3, 25. [CrossRef]

60. Wischik, C.M.; Bentham, P.; Wischik, D.J.; Seng, K.M. O3-04-07: Tau aggregation inhibitor (TAI) therapy with rember ${ }^{\text {TM }}$ arrests disease progression in mild and moderate Alzheimer's disease over 50 weeks. Alzheimers Dement. 2008, 4, 3100603. [CrossRef]

61. Wischik, C.M.; Harrington, C.R.; Storey, J.M.D. Tau-aggregation inhibitor therapy for Alzheimer's disease. Biochem. Pharmacol. 2014, 88, 529-539. [CrossRef]

62. Gauthier, S.; Feldman, H.H.; Schneider, L.S.; Wilcock, G.K.; Frisoni, G.B.; Hardlund, J.H.; Moebius, H.J.; Bentham, P.; Kook, K.A.; Wischik, D.J.; et al. Efficacy and safety of tau-aggregation inhibitor therapy in patients with mild or moderate Alzheimer's disease: A randomised, controlled, double-blind, parallel-arm, phase 3 trial. Lancet 2016, 388, 2873-2884. [CrossRef] 
63. Wilcock, G.K.; Gauthier, S.; Frisoni, G.B.; Jia, J.; Hardlund, J.H.; Moebius, H.J.; Bentham, P.; Kook, K.A.; Schelter, B.O.; Wischik, D.J.; et al. Potential of Low Dose Leuco-Methylthioninium Bis(Hydromethanesulphonate) (LMTM) Monotherapy for Treatment of Mild Alzheimer's Disease: Cohort Analysis as Modified Primary Outcome in a Phase III Clinical Trial. J. Alzheimers Dis. 2017, 61, 435-457. [CrossRef] [PubMed]

64. Surmeier, D.J. Determinants of dopaminergic neuron loss in Parkinson's disease. FEBS J. 2018, 285, 3657-3668. [CrossRef] [PubMed]

65. Dickson, D.W. Parkinson's Disease and Parkinsonism: Neuropathology. Cold Spring Harb. Perspect. Med. 2012, 2, a009258. [CrossRef]

66. Ganjam, G.K.; Bolte, K.; Matschke, L.A.; Neitemeier, S.; Dolga, A.M.; Höllerhage, M.; Höglinger, G.U.; Adamczyk, A.; Decher, N.; Oertel, W.H.; et al. Mitochondrial damage by $\alpha$-synuclein causes cell death in human dopaminergic neurons. Cell Death Dis. 2019, 10, 1-16. [CrossRef] [PubMed]

67. Subramaniam, S.R.; Chesselet, M.F. Mitochondrial dysfunction and oxidative stress in Parkinson's disease. Prog. Neurobiol. 2013, 106-107, 17-32. [CrossRef]

68. Rojas, J.C.; Simola, N.; Kermath, B.A.; Kane, J.R.; Schallert, T.; Gonzalez-Lima, F. Striatal neuroprotection with methylene blue. Neuroscience 2009, 163, 877-889. [CrossRef]

69. Wen, Y.; Li, W.; Poteet, E.C.; Xie, L.; Tan, C.; Yan, L.-J.; Ju, X.; Liu, R.; Qian, H.; Marvin, M.A.; et al. Alternative Mitochondrial Electron Transfer as a Novel Strategy for Neuroprotection*. J. Biol. Chem. 2011, 286, 16504-16515. [CrossRef] [PubMed]

70. Smith, E.S.; Clark, M.E.; Hardy, G.A.; Kraan, D.J.; Biondo, E.; Gonzalez-Lima, F.; Cormack, L.K.; Monfils, M.; Lee, H.J. Daily consumption of methylene blue reduces attentional deficits and dopamine reduction in a 6-OHDA model of Parkinson's disease. Neuroscience 2017, 359, 8-16. [CrossRef]

71. Pérez, M.J.; Jara, C.; Quintanilla, R.A. Contribution of Tau pathology to mitochondrial impairment in neurodegeneration. Front. Neurosci. 2018, 12, 1-14. [CrossRef]

72. Onyango, I.G.; Lu, J.; Rodova, M.; Lezi, E.; Crafter, A.B.; Swerdlow, R.H. Regulation of neuron mitochondrial biogenesis and relevance to brain health. Biochim. Biophys. Acta-Mol. Basis Dis. 2010, 1802, 228-234. [CrossRef]

73. Rosenkranz, S.C.; Shaposhnykov, A.A.; Träger, S.; Engler, J.B.; Witte, M.E.; Roth, V.; Vieira, V.; Paauw, N.; Bauer, S.; SchwenckeWestphal, C.; et al. Enhancing mitochondrial activity in neurons protects against neurodegeneration in a mouse model of multiple sclerosis. Elife 2021, 10, 1-60. [CrossRef]

74. Wrubel, K.M.; Riha, P.D.; Maldonado, M.A.; McCollum, D.; Gonzalez-Lima, F. The brain metabolic enhancer methylene blue improves discrimination learning in rats. Pharmacol. Biochem. Behav. 2007, 86, 712-717. [CrossRef]

75. Echevarria, D.J.; Caramillo, E.M.; Gonzalez-Lima, F. Methylene blue facilitates memory retention in Zebrafish in a dose-dependent manner. Zebrafish 2016, 13, 489-494. [CrossRef] [PubMed]

76. Auchter, A.M.; Barrett, D.W.; Monfils, M.H.; Gonzalez-Lima, F. Methylene Blue Preserves Cytochrome Oxidase Activity and Prevents Neurodegeneration and Memory Impairment in Rats With Chronic Cerebral Hypoperfusion. Front. Cell. Neurosci. 2020, 14, 1-17. [CrossRef]

77. Rodriguez, P.; Zhou, W.; Barrett, D.W.; Altmeyer, W.; Gutierrez, J.E.; Li, J.; Lancaster, J.L.; Gonzalez-Lima, F.; Duong, T.Q. Multimodal randomized functional MR imaging of the effects of methylene blue in the human brain. Radiology 2016, 281, 516-526. [CrossRef] [PubMed]

78. Zhang, S.; Duan, E. Fighting against Skin Aging: The Way from Bench to Bedside. Cell Transplant. 2018, 27, 729-738. [CrossRef]

79. Yousef, H.; Alhajj, M.; Sharma, S. Anatomy, Skin (Integument), Epidermis. StatPearls 2021. Available online: https://pubmed. ncbi.nlm.nih.gov/29262154/ (accessed on 10 October 2021).

80. Ivana, B.; Viktor, L.; Milanka, L.; Jelena, M.; Dusan, S. Skin Ageing: Natural Weapons and Strategies. Evidence-Based Complement. Altern. Med. 2013, 2013, 1-10.

81. Tobin, D.J. Introduction to skin aging. J. Tissue Viability 2017, 26, 37-46. [CrossRef]

82. Tsatsou, F.; Trakatelli, M.; Patsatsi, A.; Kalokasidis, K.; Sotiriadis, D. Extrinsic aging: UV-mediated skin carcinogenesis. Dermatoendocrinology 2012, 4, 285-297. [CrossRef]

83. Kammeyer, A.; Luiten, R.M. Oxidation events and skin aging. Ageing Res. Rev. 2015, 21, 16-29. [CrossRef]

84. Liebel, F.; Kaur, S.; Ruvolo, E.; Kollias, N.; Southall, M.D. Irradiation of skin with visible light induces reactive oxygen species and matrix-degrading enzymes. J. Investig. Dermatol. 2012, 132, 1901-1907. [CrossRef] [PubMed]

85. Atamna, H.; Nguyen, A.; Schultz, C.; Boyle, K.; Newberry, J.; Kato, H.; Ames, B.N. Methylene blue delays cellular senescence and enhances key mitochondrial biochemical pathways. FASEB J. 2008, 22, 703-712. [CrossRef]

86. Mei Xiong, Z.; O’Donovan, M.; Sun, L.; Young Choi, J.; Ren, M.; Cao, K. Anti-Aging Potentials of Methylene Blue for Human Skin Longevity. Sci. Rep. 2017, 7, 1-12. [CrossRef]

87. Xiong, Z.M.; Mao, X.; Trappio, M.; Arya, C.; el Kordi, J.; Cao, K. Ultraviolet radiation protection potentials of Methylene Blue for human skin and coral reef health. Sci. Rep. 2021, 11, 1-9. [CrossRef]

88. Gosain, A.; DiPietro, L.A. Aging and Wound Healing. World J. Surg. 2004, 28, 321-326. [CrossRef]

89. Rosique, M.J.; Rosique, R.G.; Faria, F.M.; Oliveira, C.C.; Farina, J.A.; Évora, P.R.B. Methylene blue reduces progression of burn and increases skin survival in an experimental rat model. Burns 2017, 43, 1702-1708. [CrossRef]

90. Edwards, K. New Twist on an Old Favorite: Gentian Violet and Methylene Blue Antibacterial Foams. Adv. Wound Care 2016, 5, 11-18. [CrossRef] [PubMed] 
91. Woo, K.Y.; Heil, J. A prospective evaluation of methylene blue and gentian violet dressing for management of chronic wounds with local infection. Int. Wound J. 2017, 14, 1029-1035. [CrossRef]

92. Pérez, M.; Robres, P.; Moreno, B.; Bolea, R.; Verde, M.T.; Pérez-Laguna, V.; Aspiroz, C.; Gilaberte, Y.; Rezusta, A. Comparison of Antibacterial Activity and Wound Healing in a Superficial Abrasion Mouse Model of Staphylococcus aureus Skin Infection Using Photodynamic Therapy Based on Methylene Blue or Mupirocin or Both. Front. Med. 2021, 8, 673408. [CrossRef] [PubMed]

93. Gonzalo, S.; Kreienkamp, R.; Askjaer, P. Hutchinson-Gilford Progeria Syndrome: A premature aging disease caused by LMNA gene mutations. Ageing Res. Rev. 2017, 33, 18-29. [CrossRef]

94. Capell, B.C.; Erdos, M.R.; Madigan, J.P.; Fiordalisi, J.J.; Varga, R.; Conneely, K.N.; Gordon, L.B.; Der, C.J.; Cox, A.D.; Collins, F.S. Inhibiting farnesylation of progerin prevents the characteristic nuclear blebbing of Hutchinson-Gilford progeria syndrome. Proc. Natl. Acad. Sci. USA 2005, 102, 12879-12884. [CrossRef]

95. Scaffidi, P. Lamin A-Dependent Nuclear Defects in Human Aging. Science 2006, 312, 1059-1063. [CrossRef]

96. Köhler, F.; Bormann, F.; Raddatz, G.; Gutekunst, J.; Corless, S.; Musch, T.; Lonsdorf, A.S.; Erhardt, S.; Lyko, F.; Rodríguez-Paredes, M. Epigenetic deregulation of lamina-associated domains in Hutchinson-Gilford progeria syndrome. Genome Med. 2020, 12, 1-16. [CrossRef]

97. Viteri, G.; Chung, Y.W.; Stadtman, E.R. Effect of progerin on the accumulation of oxidized proteins in fibroblasts from Hutchinson Gilford progeria patients. Mech. Ageing Dev. 2010, 131, 2-8. [CrossRef] [PubMed]

98. Lattanzi, G.; Marmiroli, S.; Facchini, A.; Maraldi, N.M. Nuclear damages and oxidative stress: New Perspectives for laminopathies. Eur. J. Histochem. 2012, 56. [CrossRef]

99. Xiong, Z.M.; Choi, J.Y.; Wang, K.; Zhang, H.; Tariq, Z.; Wu, D.; Ko, E.; Ladana, C.; Sesaki, H.; Cao, K. Methylene blue alleviates nuclear and mitochondrial abnormalities in progeria. Aging Cell 2016, 15, 279-290. [CrossRef]

100. Johri, A.; Beal, M.F. Mitochondrial dysfunction in neurodegenerative diseases. J. Pharmacol. Exp. Ther. 2012, 342, 619-630. [CrossRef] [PubMed]

101. Wischik, C.M.; Staff, R.T.; Wischik, D.J.; Bentham, P.; Murray, A.D.; Storey, J.M.D.; Kook, K.A.; Harrington, C.R. Tau Aggregation Inhibitor Therapy: An Exploratory Phase 2 Study in Mild or Moderate Alzheimer's Disease. J. Alzheimers Dis. 2015, 44, 705-720. [CrossRef] [PubMed] 